
Professor of the Department of Philosophy and Political Science Zhytomyr Ivan Franko State University, Zhytomyr, Ukraine

ORCID 0000-0002-5242-912X mykola.kozlovets@ukr.net Danylo Samoilenko, $\mathrm{PhD}$. student of the Department of Philosophy and Political Science Zhytomyr Ivan Franko State University, Zhytomyr, Ukraine ORCID 0000-0003-2316-3200 samjlenk.dank@gmail.com

\title{
MULTICULTURALISM AND TRANSLINGUISM AS COMPONENTS OF THE CULTURAL POLICY OF MODERN POLAND
}

The article considers multiculturalism as a social phenomenon, describes various aspects of its manifestation through the concept of "cultural diversity". It has been argued that the doctrine of multiculturalism proclaims the equality of cultural forms, the primacy of "cultural diversity" over ethnocultural homogeneity of states, and creates for multicultural societies a number of problems related to the plurality and cultural heterogeneity of communities. Based on the active discussion of the global multiplicity of cultures and their penetration into the value and normatively separated socio-cultural spaces, it is established that the multicultural world does not impose a single vision of reality, on the contrary, offers a field of alternative choices. The peculiarities of the functioning of multiculturalism and the policy of translinguism in modern Poland are analyzed. It is stated that an important feature of Polish multiculturalism and translinguism is the participation of national and ethnic minorities in the life of Polish society, which is realized through institutionalization of minority life, creation of various institutions and organizations designed to support their culture,

traditions and language. Recognition of cultural diversity is also manifested in the field of education: the study of minority languages is introduced in primary and secondary schools, and bilingual schools or classes are opened. The possibility of applying the positive Polish experience in the formation of multicultural policy in Ukraine is proved.

Keywords: culture, cultural diversity, cultural interaction, dialogue of cultures, multiculturalism, translinguism, communitarianism, cultural policy, Poland.

\section{Mykola Kozlowiec, Danylo Samoilenko. Wielokulturowość i translinguizm jako składniki polityki kulturalnej wspólczesnej Polski.}

Artykuł traktuje wielokulturowość jako zjawisko społeczne, opisuje różne aspekty jej

przejawiania się poprzez pojęcie "różnorodności kulturowej". Przeanalizowano specyfikę funkcjonowania wielokulturowości i polityki translingwistycznej we współczesnej Polsce. Stwierdza się, że ważna cecha polskiej wielokulturowości i translingwizmu jest udział mniejszości narodowych

$i$ etnicznych $w$ życiu polskiego społeczeństwa, który realizowany jest poprzez instytucjonalizację życia mniejszości, tworzenie różnorodnych instytucji i organizacji majacych na celu wspieranie ich kultury, tradycji i języka.

Słowa kluczowe: kultura, różnorodność kulturowa, interakcja kulturowa, dialog kultur, wielokulturowość, translinguizm, komunitaryzm, polityka kulturalna, Polska.

\section{Микола Козловець, Данило Самойленко. Мультикультуралізм і транслінгвізм у культурній політиці сучасної Польщі.}

У статті розглянуто мультикультуралізм як соиіальний феномен, охарактеризовано

різні аспекти його прояву через поняття «культурне розмаїття». Проаналізовано особливості функціонування мультикультуралізму та політику транслінгвізму в сучасній Польщіi. Констатовано, щзо важливою особливістю польського мультикультуралізму й 
Mykola Kozlovets, Danylo Samoilenko. Multiculturalism and Translinguism as Components of the Cultural Policy of Modern Poland

транслінгвізму с участь національних й етнічних меншин у житті польського суспільства, котра реалізована за допомогою інституціоналізащії життя меншин, створення різноманітних установ та організацій, покликаних підтримувати їх культуру, традииї й мову.

Ключові слова: культура, культурне розмаїття, культурна взаємодія, діалог культур, мультикультуралізм, транслінгвізм, комунітаризм, культурна політика, Польща.

Formulation of the problem. The defining characteristic of the modern world is cultural diversity, and the importance of this category will only increase in the future. Today, almost every national society can be considered multicultural. The only difference is that for some multiculturalism is the result of historical development, and for others - modern macrostructural processes, intensification of transnational movements and interethnic contacts, migration processes. In a short time, multiculturalism has become one of the most significant concepts, which plays a key role in explaining modern global processes taking place in the macro and microworlds.

Spatial and cultural diversity, the formation of increasingly "mosaic", multicultural societies, different in ethnic, cultural, religious parameters, cause difficult challenges and dangers. Theories of multiculturalism and tolerance in the form of social policy and ideology have not been tested in a number of European countries. Thus, today the secularized societies of European countries have met with the welcome of foreign religions, with the customs and traditions of migrants who do not understand them, who do not want to accept the lifestyle of the countries of which they became citizens. The division into "own" and "foreign" greatly polarizes society, governments, churches and even families. The social need to accept "strangers" into their countries, societies, local communities, and sometimes in the family has become one of the most acute problems of our time [26, p. 17-3]. The importance of this problem is evidenced by the report of the United Nations Development Program (UNDP), which states that almost a billion people (every seventh inhabitant of the Earth) belong to a group that in one form or another falls victim to ethnic, racial, religious or, more broadly, "cultural" feature [7].

One of the ways to solve these problems in multicultural societies and options for intensifying the democratization process is considered by many researchers to be multiculturalism, which "is understood not only as tolerance for cultural diversity, but also as a requirement for legislative recognition of racial, religious and cultural rights."

Discussions about cultural equality do not stop - some consider this equality something that is beyond doubt, others - are critical of such a dialogue of cultures, considering it impossible and unnecessary. Increasingly, not only scholars but also politicians and ordinary citizens are becoming critical of the possibility of "intercultural dialogue" and "unity in diversity", which is the essence of multiculturalism.

Despite repeated statements by European politicians that multiculturalism has "failed", not everyone agrees. They state the failure not of multiculturalism in general, but of its "old version", and some speak only of its transformation into other forms of cultural interaction. All this is evidence that the question of whether multiculturalism is a problem or a solution remains open.

Therefore, recourse to the analysis of the phenomenon of multiculturalism in the context of the prospects for the implementation of its principles in the social practices of European countries, in particular Poland, is extremely relevant. Although Poland is a country with a small share of national and ethnic minorities in its population, but scientists predict the inevitability of the arrival of a multicultural era and before it $[19 ; 20 ; 23 ; 24 ; 27]$.

Analysis of recent research and publications. A large number of modern multicultural studies are devoted to the study of the essence of multiculturalism as a sociocultural phenomenon, its manifestations in various spheres of public life (G. Auernheimer, P. Batelaan, K. Baker, W. Beck, D. Banks, S. Benhabib, M. Gibernau, N Glaser, R. Dworkin, WKimlika, C. Kukatas, R. Lewis, S. Muff, B. Pareh, S. Rice, J. Rawls, C. Taylor, J. Flex, N. Fresier, J. Friedman, B. Friedan, R. Henvey, etc.). Studies by these authors of historical, cultural, ethnological, political, pedagogical 
and other aspects of multiculturalism have contributed to the understanding of this phenomenon in the fullness of its incarnations in social reality. The works of P. Buchanan, S. Huntington, S. Zyzek, T. Sarratsyn, and A. Schlesinger (Jr.) are devoted to a critical understanding of the mosaic model of multiculturalism characteristic of modern society, by which he evaluates it as an ideology that threatens civic unity. national societies. Problems of multicultural education are the subject of research by J. Banks, M. Jenkins, J. Dewey, J. Lewis, S. Ramon, W. Watkins, B. Wing and other authors.

The issue of global multiplicity of cultures and the practical capacity of multicultural policy in Europe in recent years is of considerable interest to both Polish (W. Burszta, G. Gemza, Z. Glaser, M. Golka, J. Zubzycki, K. Kwasniewski, S. Łodziński, G. Mathews, J. Mucha, E. Czykwin, P. Grzybowski, T. Paleczny, A. Sadowski, W. Swiątkevych, R. Tsekera, M. Szczepanski, A. Szczliz, M. Żyromski, etc.) and domestic (O. Ananieva, O. Bandurka, Ye. Bystrytskyi, N. Vysotska, A. Kolodii, V. Mandrahelia, L. Nahorna, O. Pidskalna, M. Popovych, P. Saukh, M. Stepyko, D. Shevchuk, K. Yatsenko and others) scientists.

Recognizing the theoretical and practical significance of previous scientific work, it is necessary to recognize the lack of research to understand the specifics of the formation and functioning of social practices of multiculturalism and intercultural interactions in a multicultural society.

Of particular interest are the realities of the functioning of multicultural policy in European countries, in particular in Poland. The study of socio-cultural transformations taking place in the Republic of Poland is quite relevant for Ukraine given its chosen path of European integration, the common historical past of our peoples, the neighboring geographical location and similar sociodemographic indicators of both countries, as well as the fact that Poland has considerable experience in multicultural policy.

The purpose of the article is to analyze the peculiarities of the functioning of multiculturalism in the context of social practices of intercultural relations in modern Poland, to comprehend the positive Polish experience in order to form national multicultural practices.

Presenting main material. The concept of multiculturalism explaining the processes taking place in Western Europe, began to be actively used in the last decades of the twentieth century. The impetus was the study of ethnic differentiation of Western European societies, which was due to three groups of factors. First, protests of ethnic minorities, which were subordinated to the dominant group, intensified in Western Europe (for example, the separatist Basque movement in Spain); secondly, the growing migration of the population from the former colonies to the metropolis, which led to the formation of territories with a high proportion of immigrants (say, in the suburbs of Paris); thirdly, post-socialist transformations in the countries of Central and Eastern Europe have exacerbated the problems of national, ethnic and religious minorities of these countries [16, p. 4546; 11, p. 58].

Multiculturalism as a socio-cultural phenomenon presupposes the coexistence in society of many ethnic, national and religious groups, the implementation of the principle of cultural pluralism; recognition of equality of all ethnic and social groups; non-discrimination of people on the basis of nationality or religion, gender or age [1, p. 408]. A national minority is a group that lives compactly on the territory of a certain state and has its citizenship, but differs from the rest of the population by a smaller number, as well as ethnic, linguistic, cultural and religious characteristics and traditions [23, p. 267-268]. Such a group forms its identity through the attribution of itself to a certain nationality, organized into state structures.

The ideology of multiculturalism is based on the following principles: all individuals and minority groups are equal regardless of linguistic and cultural differences; all individuals have equal opportunities regardless of their affiliation to the relevant ethnic group, language, culture; absence of any signs of discrimination against subordinate groups; inadmissibility of racism and ethnocentrism; although there is an appropriate system of cultural norms in any society, stereotypes of culture must be avoided; it is necessary to promote awareness of the identity of minority culture; integration of society on the basis of pluralism is possible only when the group dialogue of society 
and overcome prejudices is provided [2, p. 110-121]. The main goal of multicultural policy is to form a tolerant personality, able to actively interact with representatives of other cultures on the basis of dialogue. In a multicultural society, the interaction of cultures in principle does not lead to conflict, but on the contrary, enriches every culture. Although it is possible that cultural differences generate confrontation, antagonism and even conflict.

European scientific thought in response to new socio-cultural realities (globalization and internationalization of the world, processes of ethnocultural self-determination, problems of multicultural society and migration) develops an appropriate educational strategy aimed at preserving and developing languages, cultures and identity of ethnic minorities without restrictions on access to education. . This is reflected in many documents of the UN, UNESCO, the Council of Europe, the European Union, the OSCE [3].

The American philosopher John Dewey discovered the connection between a multicultural democratic society and educational institutions. Examining the diversity of races, religious organizations, and economic associations in the United States in Democracy and Education, he noted that educational institutions should focus on balancing the various elements of society to produce common interests and sentiments. Describing the relationship between public education and a multicultural society, J. Dewey argues that by acquiring knowledge about society, students, even as representatives of different cultures, will produce a common experience and a common environment that unites a pluralistic society. The philosopher wrote: "Mixing children of different races, religions and traditions in school creates a new and wider environment for all. The common subject teaches everyone to unite views on a wider horizon than that seen by members of one group in isolation" [6].

The history of Poland's multicultural policy is organically intertwined with the general cultural policy of Europe, which is formed in the context of migration diplomacy. Thus, after the Second World War, the first wave of migration began, due to strong economic development in West Germany. In order to eliminate labor shortages, the government turned to the traditional German model of hiring and temporary recruitment of foreign workers [4]. Economic and political figures, as well as the general population, assumed that the migrant workers would return to their homeland after working for a while and accumulating some money. Based on this assumption, the authorities did not outline the need to develop any socio-political or infrastructural concepts to account for long-term residence.

Accordingly, the German government did not attach much importance to the social integration of foreigners. As a result, after 1959 the number of migrants in Germany increased sharply and by 1964 the arrival of a million "guest worker" was recorded in the country. Initially, foreign workers were used mainly as unskilled workers, they took unattractive jobs for the Germans. The economic crisis of 1966-1967 heightened tensions over the recruitment of foreign workers: West Germans, accustomed to steady economic growth in the postwar years, began to express dissatisfaction with the country's presence of cheap foreign labor. As a result, a directive was signed on November 23, 1973, prohibiting the recruitment of foreign workers, marking the end of the era of attracting foreign labor to Germany. The directive banned "guest workers" from countries that were not members of the European Economic Community.

In the early 90's of the twentieth century. the problem of foreign migration is emerging with new force, due to the collapse of the USSR, the war in the former Yugoslavia and the human rights crisis in the Kurdish region of Turkey. Ethnic Germans, Poles, and Czechs began to return to their historical homeland, and with them came the need for a new sociocultural policy. It should be noted briefly that later migrants from the Middle East and Africa brought with them a mentality, way of life and value system that had great difficulty with the mentality, way of life and values of the vast majority of Europe's indigenous people.

Therefore, the states of the European Economic Community began to justify the need for a policy of multiculturalism, "which carries the idea of decentralization, the absence of dominant 
cultural and value systems; affirms the idea of cultural and social relativism, proportionality and diversity of systems" [10, p. 190-191].

Poland is no exception in this context. At the state level, the policy of multiculturalism and tolerance is recognized and supported. Article 2 of the Constitution of the Republic of Poland states: "The Republic of Poland is a democratic state governed by the rule of law, which affirms the principles of social justice" [19]. This approach is fully consistent with the world practice of constitutional standardization of principles and provisions that are designed to promote, on the one hand, the disclosure of the concept of "democracy", and on the other - to ensure the practical implementation of the principles of cultural diversity, regional and historical cultural identity, national culture and features of intercultural interaction.

Multicultural policy in Poland in its current form began in 1989, when the country is gradually changing its official policy towards national and ethnic minorities. It was the year when Commission on National and Ethnic Minorities was established in the Sejm of the Republic of Poland. The Prime Minister Tadeusz Mazowiecki in connection with the discussion of the status of national and ethnic groups said: "We would like you to feel at home here, support your language and culture, enrich our society" [11, p. 63].

Issues related to the preservation and development of cultural identity of national and ethnic minorities are regulated by the Law on National and Ethnic Minorities and the Regional Language on January 6, 2005. This law also outlines the tasks and competences of state administration and territorial self-government in the field of interethnic relations. Its provisions are realized through the institutionalization of minority life, through the creation of various institutions and organizations designed to support their culture, traditions and language [11, p. 62].

The period of post-socialist transformation of Polish society exacerbated the problem of national and ethnic minorities, as the liberalization of social and political life was accompanied by their increasing inclusion in society, which increases their chances of preserving and developing their own culture. It is known that closure exclusively in the private sphere leads to marginalization and the disappearance of cultural differences. The condition for the participation of ethnic minorities in public life is their perception by the dominant national group, resulting in the desired state of harmonious coexistence of all citizens [11, p. 62].

Poland, as it turned out, is a country with a small share of national and ethnic minorities in its population. There are nine officially recognized national minorities in Poland. The largest community is the German community (147,094 people), it is concentrated mainly in Opole, Silesia and Warmia-Masuria. The second largest is the Belarusian minority (47,640 people), concentrated mainly in the Podlasie region. The Ukrainian minority (27,172 people) living in the border areas of Podkarpackie and Lubelskie Voivodeships, as well as in two voivodships in northeastern Poland, is also quite noticeable. In terms of numbers, the Lithuanian minority $(5,639$ people), concentrated in the north-eastern part of Podlaskie Voivodeship, also stands out. Other ethnic minorities (Russians, Slovaks, Jews, Czechs, Armenians) are not so numerous [11, p. 63]. It is estimated that non-Polish nationalities number almost 1 million people, which is $3 \%$ of the total population. Some citizens belonging to national and ethnic minorities live compactly; the other is scattered [23, p. 272]. There are two regions where the level of multiculturalism is quite high due to the fact that those ethnic and national minorities living in them are increasingly openly expressing their cultural diversity. These are Upper Silesia and Podlaskie Voivodeship. But also in other territories of modern Poland - in Polish metropolises - the manifestations of multiculturalism become more noticeable due to the macrostructural processes that take place in Polish society, primarily migration. Polish non-ethnic multiculturalism is observed mainly in Polish cities. It manifests itself as a cultural diversity of social space, which adds a special flavor to culture and promotes tolerance and social development $[11$, p. 65].

O. Pidskalna in her scientific research "Peculiarity of multicultural practice in Poland" notes that today in Poland everything can be multicultural, because multiculturalism is fashionable and well 
received. Many towns and villages hold multinational festivals and fairs, which testifies to the ancient cultural diversity of the regions [5, p. 81-96].

However, it should be noted that the peculiarity of the functioning of Polish multiculturalism is the perception of "others", but in accordance with strict rules that prevent the violation of the core of the dominant culture. That is, multiculturalism becomes an instrument of strengthening Polishness, or more precisely, a concrete vision of Polishness, mediated through the historical perception of Poland as an ethnic-Polish and Catholic country.

The problem is that the officially declared multicultural policy of the Polish government does not always find its mechanism of real functioning in the political sphere. Moreover, in the multicultural Polish discourse there is a paradoxical opinion that with all the declaration of multiculturalism and, consequently, the protection of the political rights of national minorities, it in reality acts as a mechanism for strengthening the Polish ethnocentric idea. This is the position of Polish researcher Agnieszka Pasika, who in her article "Polish Multicultural Policy of Multiculturalism as a Mechanism for Strengthening Polishness" states: "... The category "multiculturalism" is a mechanism that, instead of explaining to society the real cultural diversity, strengthens the Polish and Polish-Catholic dominance "[24, p. 130]. The researcher comes to this conclusion by analyzing the data of field research in the Usti-Horlytske commune, where both Poles and a significant number of representatives of ethnic minorities, primarily Lemkos, live in the same territory.

According to the researcher, the success of the implementation of multicultural principles in practice, directly depends on the formation of representatives of different cultures of common civic values, which should perform an integrative function in society. However, it is the difficulty of forming a single civic position for all cultural components of society, built on the principles of tolerance and humanism, that is the "weak" place of multiculturalism. The lack of a common position in a multicultural society around a system of common civic guidelines also creates the main social dangers of this ideology (cultural autarky, marginalization of minorities, etc.). The main reason for such dangers, according to $\mathrm{K}$. Yatsenko, are antagonistic cultural or confessional contradictions between representatives of titular nations and marginal minorities that make it impossible to form a common civic position for all cultures [13, p. 20-25].

An example of such social antagonisms was the position of radical Muslims, especially in Europe, which significantly discredited the policy of multiculturalism, the collapse and harmfulness of which has already been declared not only by the heads of governments of Germany, France and Britain, but also by political circles. and Poland [6]. Therefore, under conditions of maximum tolerance of relations between cultures, state structures must remain effective tools to combat cultural and religious radicalism. Only with such a state position can a society where cultural policy is implemented by communities function and develop effectively.

This is confirmed by the "soft power" language policy, which enables a bilingual (multilingual) learning environment in Polish educational institutions, especially in regions where representatives of different ethnic and linguistic groups live. Bilingual and multilingual education improves relations between different groups of the population and promotes the spread of translinguism in various spheres of public life. Translinguism arises in a communication situation in which an individual uses several language systems, moves from one language code to another, resulting in: 1) merging of several linguistic cultures while fully preserving the linguistic and cultural identity of native speakers and 2) the formation of mixed discourses [14]. Translinguism presupposes the penetration of one language into another, the emergence of a new quality of enriched linguistic culture.

Transculture, which emerges as a result of transculturalism and is closely related to translinguism, means "a new sphere of cultural development outside the established national, racial, gender and professional cultures" by overcoming "closed traditions, language and value determinations" [8, with. 55].

Transculture encompasses the simultaneous existence of an individual in the field of several identities in different cultures, with the partial preservation of each of them. The author of the term 
translinguism Fernando Ortiz notes that as a result of transculturation a new sphere of cultural development emerges outside the established national, racial, gender and professional cultures by overcoming the isolation of their traditions, language and value determinations [20]. At transculturation there is a hybridization of cultures. In other words, transculturalism overcomes the cultural separatism, isolation, stratification and determinism of identity by the discourse of authenticity that have become the basis for multiculturalism. Transculturalism encompasses the focus on self-distancing, self-removal from any predetermined identity and self-criticism. Transculturalism presupposes the coexistence in different cultures with the preservation of the imprints of each of them. The result of transculturalism is a gradual change of culture, including through hybridization; acceptance of differences ("reconciling differences" $[15$, p. 8]), because the individual acts as several identities in one and in another culture.

In connection with the above, Poland has introduced an inclusive and pragmatic approach to cultural policy, taking into account linguistic diversity, taking into account the real needs of different groups of society, aimed at achieving balance, compromise and reconciliation. Such a policy must strive for full respect for the rights of persons belonging to national minorities, for peaceful interaction between people of different ethnic and national backgrounds and for the creation of equal opportunities for the participation of every human being in society. Therefore, Poland creates an environment where diversity is not considered a threat, where all members of society can safely use their native language without fear of discrimination, and where at the same time everyone can speak the same common state language.

The formation of a common identity does not necessarily lead exclusively to the use of one language. A common identity can be built on other, more inclusive values, such as shared traditions, shared citizenship over linguistic and ethnic differences, a shared vision of the future, and a recognition of diversity as a source of prosperity, collective resilience, and trust.

Conclusions and prospects for further research. Multiculturalism as a phenomenon at the present stage of development of society is not perceived as a strategy created on the basis of extreme cultural relativism, but arises as a social discourse that recognizes the feasibility and meaning of cultural diversity. With the complication of the guidelines of the spiritual life of society, the intensification of transnational movements and interethnic contacts, migration processes, changes in ideological and political vectors of development, intercultural interactions acquire a new quality.

Political, social and economic changes in Central and Eastern Europe, including Poland, at the beginning of the XXI century increased migration flows. The influx of refugees and immigrants has led to processes of new population diversification and modification of public consciousness in ethnic and cultural dimensions. It is in nation-states that migration and cultural diversity, as a process that accompanies it, meet the greatest resistance, and therefore the task of understanding the cultural and social transformations caused by migration acquires special significance in them. Cultural diversity contributes to the development of a pluralistic view of the world, within which a multicultural society is understood and perceived with such consequences as translinguism.

The most important feature of Polish multiculturalism and translinguism is the participation of national and ethnic minorities in the life of Polish society, which is realized through the institutionalization of minority life, the creation of various institutions and organizations designed to support their culture, traditions and language. Recognition of cultural diversity is also manifested in the field of education: the study of minority languages is introduced in primary and secondary schools, and bilingual schools or classes are opened. The multicultural world does not impose a person to a single vision of reality, on the contrary, offers a field of alternative choices.

\section{Список використаних джерел та літератури}

1. Баксанский О. Е. Национальный проект «Образование» и Болонский процесс. Россия : многообразие культур и глобализация / отв. ред. И. К. Лисеев. Москва: Канон+; Реабилитация, 2010. C. $406-431$. 
Mykola Kozlovets, Danylo Samoilenko. Multiculturalism and Translinguism as Components of the Cultural Policy of Modern Poland

2. Висоцька Н. О. $\quad$ Концепція мультикультуралізму i літературознавства: Науковий збірник. Чернівці: Рута, 2009. Вип. 77. С. 110-121.

3. Європейська хартія регіональних або міноритарних мов. Режим доступу: https://zakon.rada.gov.ua/laws/show/994_014\#Tехt [дата звернення: 23.10.2020].

4. Методология и методы изучения миграционных процессов / под ред. Ж. Зайончковской, И. Молодиковой, В. Мукомеля. Москва: Наука, 2007. 371 с.

5. Підскальна О. М. Особливість мультикультурної практики в Польщі. Украӥнська полоністика. 2016. Вип. 13. С. 81-96.

6. Полина И. Глава МВД Польши: политкорректность и мультикультурализм - самоубийство для Европы [Електронний ресурс]. Международная панорама. 2016. Режим доступу: http://124.1t/ru/vmire/item/140618-2016-07-26-08-16-13 [дата звернення: 22.10.2020].

7. Ronan Le Coadic. Во Франции нет меньшинств. VIII Конгресс этнографов и антропологов России, Jul 2009, Orenbourg, Russia. pp.6-11.

8. Тлостанова М. В. От философии мультикультурализма к философии транскультурации. Москва: РУДН, 2008. $251 \mathrm{c.}$

9. Фукуяма Ф. Против политики идентичности http://sg-sofia.com.ua/protiv-politiki-identichnostifukuyama [дата звернення: 22.10.2020].

10. Шевчук Д. Сучасна політична філософія : навч. посіб. Острог : Видавництво Національного університетуту «Острозька академія», 2012. 347 с.

11. Щлиз А., Шчепаньски М. С. Социологический смысл мультикультурализма: является ли Польша мультикультурной? Соииологические исследования. 2014. № 2 (Февраль). С. 58-67.

12. Ярославна Лєбєдєва, Олександр Рудік. Засади мультикультурної освіти на європейському просторі https://ainstud.at.ua/_ld/0/67_Lebedeva_multic.pdf [дата звернення: 22.10.2020].

13. Яценко К. А. Європейський Союз та виклики мультикультуралізму. Інтермарум: історія, політика, культура. 2017. № 4. С. 17-32.

14. Bubnova, I. A., Zykova N. V., Krasnyh V. V., and N. V. Ufimceva. 2017. (Neo)psiholingvistika i (psiho)lingvokul'turologiya: novye nauki o cheloveke govoryashchem [(Neo)psycholinguistics and (Neo)linguoculturology: New Sciences about Homo Loquens]. Moscow: Gnozis.

15. Fishman J. Endangered Minority Languages: Prospects for Sociolinguistic Research. International Journal on Multicultural Societies. 2002. Режим доступу до ресурсу: http://unesdoc.unesco.org/images/0013/001387/138795e.pdf. [дата звернення: 22.10.2020].

16. Grzybowski P. P. Edukacja europejska - od wielokulturowości ku międzykulturowiści. Warszawa: Warszawskie Wydawnictwo Literackie MUZA SA, 2007.

17. Golka M. Imiona wielokulturowości. Warszawa: Warszawskie Wydawnictwo Literackie MUZA SA, 2010.

18. Konstytucja Rzeczypospolitej Polskiej z dnia 2 kwietnia 1997 r. Dziennik Ustaw, 1997. nr 78. poz. 483.

19. Kwaśniewski K. Pluralizm kultury. Tożsamość kulturowa // Słownik etnograficzny / Z. Staszczak (red.). Warszawa; Poznań, 1987.

20. Maher J. C. Metroethnicity, language, and the principle of Cool. International Journal of the Sociology of Language. Volume 2005, Issue 175-176. P. 83-102.

21. Mathews G. Supermarket kultury, tłum. E. Klekot. Warszawa: Państwowy Instytut Wydawniczy, 2005.

22. Mucha J. Wielokulturowość etniczna i nieetniczna // Sprawy Narodowościowe. 1999. Nr. 14-15.

23. Nikitorowicz J. Grupy etniczne w wielokulturowym świecie. Gdańskie Wydawnictwo Psychologiczne. Sopot, 2010.

24. Pasieka A. Wielokulturowych po polsku o polityce wielokulturowości jako mechanizmie umacniania polskości. Kultura i spoteczeństwo. Warszawa : PAN, Komitet socjologii, Instytut studiów politycznych, 2013. № 3. S. 129-155.

25. Taylor Ch. Sources of the Self: The Making of the Modern Identity. Cambridge, 1989

26. Swoj i obcy w kontekście współczesnego kryzysu migracyjnego. Doświadczenia i zadania Kościołow i społeczeństwa. Redakcja naukowa Zygfryd Glaeser Grzegorz Giemza. Warszawa: Warto, 2017. $526 \mathrm{~s}$.

27. Zubrzycki J. Rozmowa $\mathrm{z}$ Prof. Jerzy Zabrzyckim. 2010. URL: http://www.tolerancja.pl/?jerzyzubrzycki,262 (дата звернення: 22.10.2020).

\section{References (translated \& transliterated)}

1. Baksanskyi, O. (2010) Natsionalnyi proekt "Osvita" i Bolonskyi protses. Rosiia: riznomanittia kultur $i$ hlobalizatsiia. [National project "Education" and the Bologna process. Russia: cultural diversity and globalization] Moskva: Kanon +; Reabilitatsiia. 406-431 [in Russian]. 
2. Vysotska, N. (2009) Kontseptsiia multykulturalizmu i pytannia estetyky. [The concept of multiculturalism and issues of aesthetics.] Pytannia literaturoznavstva: Naukovyi zbirnyk. Chernivtsi: Ruta. 77. 110-121 [in Ukrainian].

3. Yevropeiska khartiia rehionalnykh abo minorytarnykh mov. [European Charter for Regional or Minority Languages.] Retrieved from: https://zakon.rada.gov.ua/laws/show/994_014\#Text [in Ukrainian].

4. Zaionchkovska, Zh., Molodikova, I., Mukomel, V. (2007) Metodolohiia $i$ metody vyvchennia mihratsiinykh protsesiv. [Methodology and Methods of Studying Migration Processes] Moskva: Nauka [in Russian].

5. Pidskalna, O. (2016) Osoblyvist multykulturnoi praktyky v Polshchi. [Peculiarity of multicultural practice in Poland.] Ukrainska polonistyka. 2016. 13. 81-96 [in Ukrainian].

6. Polina, I. (2016) Holova MVS Polshchi: politkorektnist i multykulturalizm - samohubstvo dlia Yevropy. Mizhnarodna panorama. Retrieved from: http://124.1t/ru/v-mire/item/140618-2016-07-26-08-16-13 [in Russian].

7. Coadik, R. (2009) U Frantsii nemaie menshyn [There are no minorities in France.] VIII Congress of Ethnographers and Anthropologists of Russia. Orenbourg, Russia. 6-11 [in Russian].

8. Tlostanova, M. (2008) Vid filosofii multykulturalizmu do filosofii transkulturatsii. [From the philosophy of multiculturalism to the philosophy of transculturalism] Moskva: RUDN [in Russian].

9. Fukuiama, F. Proty polityky identychnosti [Against identity politics] http://sg-sofia.com.ua/protiv-politikiidentichnosti-fukuyama [in Russian].

10. Shevchuk, D. (2012) Suchasna politychna filosofiia : navch. posib. [Modern political philosophy: textbook.] Ostroh: Vydavnytstvo Natsionalnoho universytetutu "Ostrozka akademiia". 347. [in Ukrainian].

11. Shchliz, A., Shchepanski M. (2014) Sotsiolohichnyi zmist multykulturalizmu: chy ye Polshcha multykulturnoiu? [Sociological meaning of multiculturalism: is Poland multicultural?] Sotsiolohichni doslidzhennia. 2. 58-67 [in Russian].

12. Liebiedieva, Ya., Rudik, O. Zasady multykulturnoi osvity na yevropeiskomu prostori [Principles of multicultural education in Europe] Retrieved from: https://ainstud.at.ua/_ld/0/67_Lebedeva_multic.pdf [in Ukrainian].

13. Yatsenko, K. (2017) Yevropeiskyi Soiuz ta vyklyky multykulturalizmu. Intermarum: istoriia, polityka, kultura. [The European Union and the challenges of multiculturalism.] 4. 17-32 [in Ukrainian].

14. Bubnova, I., Zykova, N., Krasnyh, V., Ufimceva, N. (2017). (Neo)psiholingvistika I (psiho)lingvokul'turologiya: novye nauki o cheloveke govoryashchem [(Neo)psycholinguistics and (Neo)linguoculturology: New Sciences about Homo Loquens]. Moscow: Gnozis [in Russian].

15. Fishman, J. (2002) Endangered Minority Languages: Prospects for Sociolinguistic Research. International Journal on Multicultural Societies. Retrieved from: http://unesdoc.unesco.org/images/0013/001387/138795e.pdf [in English].

16. Grzybowski, P. (2007) Edukacja europejska - od wielokulturowości ku międzykulturowiści. [European education - from multiculturalism to interculturalism.] Warszawa: Warszawskie Wydawnictwo Literackie MUZA SA [in Polish].

17. Golka, M. (2010) Imiona wielokulturowości. [Names of multiculturalism.] Warszawa: Warszawskie Wydawnictwo Literackie MUZA SA [in Polish].

18. Konstytucja Rzeczypospolitej Polskiej z dnia 2 kwietnia 1997 r. Dziennik Ustaw, 1997. nr 78. poz. 483. [Constitution of the Republic of Poland of 2 April 1997. Journal of Laws, 1997. no 78, item 483.] [in Polish].

19. Kwaśniewski, K. (1987) Pluralizm kultury. Tożsamość kulturowa. [Pluralism of culture. Cultural identity] Słownik etnograficzny. Warszawa; Poznań [in Polish].

20. Maher, J. (2005) Metroethnicity, language, and the principle of Cool. International Journal of the Sociology of Language. 175-176. 83-102 [in English].

21. Mathews, G. (2005) Supermarket kultury, thum. E. Klekot. [Cultural Supermarket, trans. E. Klekot] Warszawa: Państwowy Instytut Wydawniczy [in Polish].

22. Mucha, J. (1999) Wielokulturowość etniczna i nieetniczna. [Ethnic and non-ethnic multiculturalism.] Sprawy Narodowościowe. 14-15 [in Polish].

23. Nikitorowicz, J. (2010) Grupy etniczne w wielokulturowym świecie. Gdańskie Wydawnictwo Psychologiczne. [Ethnic groups in a multicultural world.] Sopot [in Polish].

24. Pasieka, A. (2013) Wielokulturowych po polsku o polityce wielokulturowości jako mechanizmie umacniania polskości. Kultura $i$ spoleczeństwo. [Multiculturalism in Poland. The policy of multiculturalism as a mechanism of strengthening Polishness.] Warszawa: PAN, Komitet socjologii, Instytut studiów politycznych, 3. 129-155 [in Polish].

25. Taylor, Ch. (1989) Sources of the Self: The Making of the Modern Identity. Cambridge [in English]. 
Mykola Kozlovets, Danylo Samoilenko. Multiculturalism and Translinguism as Components of the Cultural Policy of Modern Poland

26. Giemza, Z. (2017) Swoj i obcy w kontekście wspótczesnego kryzysu migracyjnego. Doświadczenia $i$ zadania kościolow $i$ spoteczeństwa. [Home and foreign in the context of the contemporary migration crisis. Experiences and tasks of the Church and society.] Warszawa: Warto [in Polish].

27. Zubrzycki, J. (2010) Rozmowa z Prof. Jerzy Zabrzyckim. [Interview with Prof. Jerzy Zabrzycki.] Retrieved from: http://www.tolerancja.pl/?jerzy-zubrzycki,262 [in Polish].

Статтю отримано $26.10 .2020 \mathrm{p}$.

Прийнято до друку 27.11.2020 p. 